\title{
MASALAH YURIDIS TIDAK DITETAPKANNYA KUALIFIKASI DELIK DALAM KETENTUAN PIDANA PADA UNDANG-UNDANG YANG DISAHKAN DALAM KURUN WAKTU 2015-2019
}

\author{
Ade Adhari $^{1}$, Anis Widyawati ${ }^{2}$, Fajar Dian Aryani ${ }^{3}$, Musmuliadin ${ }^{4}$ \\ ${ }^{1}$ Fakultas Hukum, Universitas Tarumanagara, Jakarta \\ Email: adea@fh.untar.ac.id \\ ${ }^{2}$ Fakultas Hukum, Universitas Negeri Semarang, Semarang \\ Email: aniswidya02@gmail.com \\ ${ }^{3}$ Fakultas Hukum, Universitas Pancasakti Tegal, Tegal \\ Email: fajardi4n@gmail.com \\ ${ }^{4}$ Prodi Hukum, Sekolah Tinggi Ilmu Hukum Muhammadiyah, Bima \\ Email: musmuliadinbima1992@gmail.com
}

Masuk : 06-03-2021, revisi: 30-04-2021, diterima untuk diterbitkan : 30-04-2021

\begin{abstract}
In the 2015-2019 period, there were 20 (twenty) ratifications and promulgations of laws in which there were policies for the formulation of criminal provisions. Chapter Criminal Provisions in various laws have a strategic position so that criminal law norms can be operational properly at the level of application and execution of crimes. However, at the in abstracto level, the formulation of criminal provisions in these various laws contains juridical problems. The research method used to answer these problems is doctrinal research by conceptualizing law is statutory regulation. There is a criminal law issued in the 2015-2019 period which is the object of study. The results showed that the juridical problems found were, among others, 19 laws that did not stipulate juridical qualifications in the form of crimes or violations. The distinction between crimes and violations has a juridical consequence in the form of differentiating penalties for crimes and violations in Book I of the Criminal Code. The absence of a determination of this juridical qualification means that the general provisions in Book I of the Criminal Code Chapter I-XVIII cannot be enforced. Therefore, it is necessary to reform the criminal law towards the formulation policy by improving the formulation of criminal law norms which contain juridical issues in these various laws.
\end{abstract}

Keywords: criminal law policies; formulation policies; criminal provision; juridical issues.

ABSTRAK
Dalam kurun waktu 2015-2019 terdapat 20 (dua puluh) pengesahan dan pengundangan undang-undang yang didalamnya terdapat kebijakan formulasi ketentuan pidana. Bab Ketentuan Pidana dalam berbagai undang-undang memiliki posisi yang strategis agar norma hukum pidana dapat operasional dengan baik pada tataran aplikasi dan eksekusi pidana. Namun dalam tataran in abstracto, formulasi ketentuan pidana dalam berbagai undang-undang tersebut mengandung masalah yuridis. Metode penelitian yang digunakan untuk menjawab permasalahan tersebut adalah penelitian doktrinal dengan mengkonsepsikan hukum adalah peraturan perundang-undangan. Terdapat undang-undang pidana yang terbit pada periode 2015-2019 yang menjadi objek kajian. Hasil penelitian menunjukan masalah yuridis yang ditemukan antara lain terdapat 19 undang-undang yang tidak menetapkan kualifikasi yuridis berupa kejahatan atau pelanggaran. Pembedaan kejahatan dan pelanggaran mengandung konsekuensi yuridis berupa adanya pembedaan aturan pemidanaan bagi kejahatan dan pelanggaran yang ada dalam Buku I KUHP. Tidak adanya penetapan kualifikasi yuridis ini menyebabkan ketentuan umum dalam Buku I KUHP Bab I-XVIII tidak dapat diberlakukan. Oleh sebab itu diperlukan pembaharuan hukum pidana terhadap kebijakan formulasi tersebut dengan memperbaiki perumusan norma hukum pidana yang memuat masalah yuridis dalam berbagai undang-undang tersebut.

Kata Kunci: kebijakan hukum pidana, kebijakan formulasi, ketentuan pidana, masalah yuridis.

\section{PENDAHULUAN}

\section{Latar Belakang}

Sanksi pidana merupakan salah satu sarana yang dipilih dan digunakan untuk menanggulangi kejahatan. Penanggulangan kejahatan dengan menggunakan sanksi pidana dikenal dengan kebijakan hukum pidana (penal policy). Penggunaan kebijakan hukum pidana dalam 
menanggulangi kejahatan menjadi dasar berjalannya sistem peradilan pidana (criminal justice system). PBB dalam berbagai kongresnya menyatakan bahwa sistem peradilan pidana merupakan bagian dari cara menanggulangi kejahatan, disamping kebijakan pencegahan kejahatan. Hal tersebut disimpulkan dari berbagai pernyataan yang menyatakan (Seventh UN Congress, 1985; Eighth UN Congress, 1990):

Crime prevention and criminal justice should be considered in the context of economic development, political systems, social and cultural values and social change, as well as in the context of the new international economic order. The criminal justice system should be fully responsive to the diversity of political, economic, and social systems and to the constantly evolving conditions of society". (Pertimbangan No. 4, pen.) atau pernyataan selanjutnya Convinced that crime prevention and criminal justice in the context of development should be oriented towards the observance of the principles contained in the Caracas Declaration, the Milan Plan of action, the Guiding Principles for Crime Prevention and Criminal Justice in the Context of Development and a New International Economic Order and other relevant resolutions and recommendations of the Seventh United Nations Congress on the of prevention crime and the Treatment of Offenders

Frasa "Crime prevention and criminal justice" menunjukan sistem peradilan pidana menjadi salah satu sarana yang dapat dipilih oleh negara untuk mengatasi kejahatan. Operasionalnya sanksi pidana dalam menanggulangi kejahatan melalui 3 (tiga) tahapan. Tahapan tersebut antara lain tahap formulasi (formulation stage), tahap aplikasi (aplication stage) dan tahap eksekusi (execution stage). Semua tahapan tersebut saling terkait dan tidak bisa dipisah $\downarrow$ lepaskan, dan bekerja untuk mencapai tujuan yang ditetapkan. Tahapan formulasi disebut juga dengan kebijakan formulasi (formulation policy) merupakan tahapan merumuskan norma hukum pidana. Barda Nawawi Arief memandangnya sebagai tahap perencanaan awal yang sangat strategis dari proses penegakan hukum "in concreto (Arief, 2016). Dikatakan strategis karena, memberikan landasan, arah, substansi, dan batasan kewenangan dalam penegakan hukum yang akan dilakukan oleh pengemban kewenangan yudikatif maupun eksekutif (Arief, 2016).

Tahap formulasi diwujudkan melalui proses pembentukan peraturan perundang-undangan yang di dalamnya memuat norma hukum pidana. Pembentukan norma hukum pidana diatur dalam Undang-Undang Nomor 12 Tahun 2011 tentang Pembentukan Peraturan Perundang-Undangan yang terakhir dirubah dengan Undang-Undang Nomor 15 Tahun 2009 tentang Perubahan atas Undang-Undang Nomor 12 Tahun 2011 tentang Pembentukan Peraturan Perundang-Undangan (UU Pembentukan Peraturan Perundang-Undangan). Dalam Pasal 15 undang-undang tersebut hanya 2 (dua) jenis regulasi yang dapat memuat norma hukum pidana yaitu undang-undang dan peraturan daerah.

Undang-undang dan peraturan daerah dalam kebijakan hukum pidana memiliki posisi yang penting. Karena menjadi panduan dalam penegakan hukum pidana. Sehingga harus dipastikan dirumuskan sebaik mungkin, seminimal mungkin tidak mengandung masalah yuridis. Meminjam definisi yang diberikan oleh Arief (2016), "masalah yuridis" (dalam kebijakan formulasi) adalah suatu masalah perumusan "dilihat dari kebijakan formulasi yang seharusnya" (menurut sistem hukum pidana/sistem pemidanaan yang berlaku).

Sistem hukum pidana saat ini terdapat dalam Kitab Undang-Undang Hukum Pidana (KUHP) dan Ketentuan Pidana yang terdapat dalam Peraturan Perundang-Undangan diluar KUHP yaitu UU atau Perda. Ketentuan pidana dalam UU atau Perda merupakan sub-sitem dari hukum pidana yang berinduk pada KUHP. Sebagai bagian dari sistem hukum pidana, ketentuan pidana dalam UU atau 
Perda terikat pada aturan umum pemidanaan (general rules of sentencing atau algemene leerstukken) yang terdapat dalam Buku I KUHP Bab I sampai dengan Bab VIII (Pasal 1-85). Menurut Pasal 103 KUHP aturan umum tersebut berlaku bagi setiap tindak pidana baik yang diatur dalam Buku II-III KUHP, dan Ketentuan pidana dalam undang-undang dan perda sepanjang tidak diatur secara khusus. Artinya, apabila undang-undang tidak mengatur secara khusus, maka aturan umum pemidanaan dalam KUHP dapat diberlakukan. Untuk dapat memberlakukan aturan pemidanaan umum dalam KUHP, maka harus ada penetapan kualifikasi yuridis terhadap setiap tindak pidana yang diatur dalam ketentuan pidana suatu UU apakah termasuk kejahatan atau pelanggaran. Hal ini dikarenakan KUHP memiliki aturan umum pemidanaan yang berbeda bagi kejahatan dan pelanggaran. Apabila tidak dilakukan akan sulit menerapkan aturan pemidanaan umum yang telah tersedia dalam KUHP $\downarrow$ inilah yang disebut masalah yuridis.

Pasal 103 KUHP memberikan peluang bagi pembentuk undang-undang untuk memuat ketentuan yang bersifat khusus atau menyimpang dari Bab I-VIII Buku I KUHP. Sehingga apabila pembentuk undang-undang menetapkan aturan pemidanaan yang khusus yang menyimpang, maka seharusnya aturannya dibuat dengan lengkap. Apabila tidak dibuat dengan lengkap, inilah yang mengakibatkan adanya masalah yuridis. Aparat penegak hukum tidak memiliki aturan pemidanaan khusus yang lengkap yang dapat digunakan sebagai pedoman dalam memproses suatu tindak pidana. Masalah yuridis dapat dikatakan sebagai kelemahan dari kebijakan formulasi. Kelemahan kebijakan formulasi hukum pidana akan berpengaruh pada kebijakan penegakan hukum pidana dan kebijakan penanggulangan kejahatan (Arief, 2016). Keberadaan masalah yuridis menjadi dasar untuk mengadakan pembaharuan kebijakan formulasi ketentuan pidana yang terdapat dalam undang-undang yang disahkan dan diundangkan dalam kurun waktu 2015-2019.

\section{METODE PENELITIAN}

Penelitian ini termasuk dalam kategori atau kualifikasi doctrinal research. Doktrinal research dapat dimaknai dengan "research which provides systematic exposition of the rules governing a particular legal category, analyses between rules, explain areas of difficulty and, perhaps, predicts future development (Chynoweth, 2008). Dengan demikian penelitian jenis ini berorientasi melakukan penelaahan terhadap aturan hukum yang ada saat ini, dan kemudian hasil penelaahan tersebut dijadikan sebagai dasar rekonstruksi hukum di masa depan. Penelitian ini melakukan inventarisasi dan kajian mendalam terhadap peraturan perundang-undangan yang terbit pada periode 2015-2019 yang di dalamnya terdapat bab tentang ketentuan pidana.

\section{HASIL DAN PEMBAHASAN}

Sanksi pidana merupakan sarana yang semakin masif penggunaanya, utamanya di Indonesia. Digunakannya sanksi pidana untuk menanggulangi kejahatan, dapat ditemukan dalam KUHP dan Ketentuan Pidana yang terdapat dalam peraturan perundang-undangan diluar KUHP (UndangUndang atau Perda). Ketentuan pidana dalam undang-undang diluar KUHP merupakan bagian dari Sistem Hukum Pidana yang saat ini berinduk atau berpangkal pada KUHP. Dalam perumusan Ketentuan Pidana, UU Pembentukan Peraturan Perundang-Undangan telah menetapkan ramburambunya. Rambu-rambu tersebut dirumuskan dalam rumusan pasal dalam batang tubuhnya maupun lampiran undang-undang tersebut.

Pada batang tubuh UU Pembentukan Peraturan Perundang-Undangan, tepatnya pada Pasal 15 diatur materi muatan mengenai ketentuan pidana hanya dapat dimuat dalam undang-undang, peraturan daerah provinsi atau peraturan daerah kabupaten/kota. Ketentuan pidana yang terdapat dalam peraturan daerah peraturan daerah provinsi atau peraturan daerah kabupaten/kota memiliki batasan (limitation atau restriction) berupa hanya dapat merumuskan ancaman pidana kurungan 
paling lama 6 (enam) bulan atau pidana denda paling banyak Rp 50.000.000 (lima puluh juta rupiah). Lebih lengkap lagi, dalam Lampiran C3 No. 112-126 UU Pembentukan Peraturan Perundang-Undangan dirumuskan pedoman bagaimana merumuskan "Ketentuan Pidana".

Ketentuan Pidana dalam berbagai undang-undang diluar KUHP dalam perspektif "Pembangunan Sistem Hukum Nasional" dapat dikatakan sebagai bagian kecil dari luasnya ruang lingkup pembangunan SHN, tepatnya bagian dari pembangunan substansial. Terkait dengan hal tersebut Arief (2012) menyatakan:

Ruang lingkup pembangunan SHN dapat dilihat dari berbagai aspek/sudut. Apabila dilihat dari ruang lingkup SHN sebagaimana dikemukakan di atas, maka pembangunan ruang lingkup SHN dapat mencakup pembangunan "substansial" (sub-stansi hukum/legal substance), pembangunan "struktural" (struktur hukum/legal structure), dan pembangunan "kultural" (budaya hukum/legal culture).

Ketentuan Pidana dengan demikian bagian dari substansi hukum pidana nasional yang harus dibangun dan dievaluasi sehingga hukum pidana mampu mencapai tujuannya yaitu melindungi masyarakat (social defence). Untuk itu ketentuan pidana harus dipastikan tidak memuat masalah yuridis.

Untuk mengkaji masalah yuridis yang terdapat dalam ketentuan pidana suatu undang-undang, maka perlu diinventarisir terlebih dahulu berbagai undang-undang yang telah disahkan dan diundangkan. Dalam kurun waktu 2015-2019 terdapat banyak undang-undang-undang yang ditetapkan. Berikut disajikan tabel yang bersisi mengenai inventarisir terdahap undang-undang yang memuat ketentuan pidana.

Tabel 1.

Inventarisasi Ketentuan Pidana dalam Undang-Undang yang Disahkan dalam Kurun Waktu 2015-2019

\begin{tabular}{cll}
\hline No. & \multicolumn{1}{c}{ Undang-Undang } & \multicolumn{1}{c}{$\begin{array}{c}\text { Ketentuan Pidana } \\
\text { Materiil dan Formil }\end{array}$} \\
\hline 1. & $\begin{array}{l}\text { Undang-Undang Nomor 11 Tahun } \\
\text { 2019 tentang Sistem Nasional Ilmu } \\
\text { Pengetahuan dan Teknologi }\end{array}$ & Bab XII Ketentuan Pidana Pasal 93-96 \\
\hline 2. & $\begin{array}{l}\text { Undang-Undang Nomor 8 Tahun } \\
\text { 2019 tentang Penyelenggaraan }\end{array}$ & Bab XII Ketentuan Pidana Pasal 120-126 \\
Ibadah Hajii dan Umroh & Bab X Penyidikan Pasal 112 \\
\hline 3. Undang-Undang Nomor 9 Tahun & Bab XI Ketentuan Pidana Pasal 67-68 \\
2018 tentang Penerimaan Negara \\
Bukan Pajak
\end{tabular}




\begin{tabular}{|c|c|c|}
\hline 7. & $\begin{array}{l}\text { Undang-Undang Nomor } 16 \text { Tahun } \\
2017 \text { tentang Penetapan Peraturan } \\
\text { Pemerintah Pengganti Undang- } \\
\text { Undang Nomor } 2 \text { Tahun } 2017 \\
\text { tentang Perubahan atas Undang- } \\
\text { Undang Nomor 2 Tahun 2013 } \\
\text { tentang Organisasi Kemasyarakatan } \\
\text { Menjadi Undang-Undang }\end{array}$ & Bab XVIIA Ketentuan Pidana Pasal 82A \\
\hline 8. & $\begin{array}{l}\text { Undang-Undang Nomor } 7 \text { Tahun } \\
2017 \text { tentang Pemilihan Umum }\end{array}$ & $\begin{array}{l}\text { Buku Kelima Tindak Pidana Pemilu } \\
\text { Bab I Penanganan Tindak Pidana Pemilu } \\
\text { Bab II Ketentuan Pidana Pemilu Pasal 488-554 }\end{array}$ \\
\hline 9. & $\begin{array}{l}\text { Undang-Undang Nomor } 5 \text { Tahun } \\
2017 \text { tentang Pemajuan Kebudayaan }\end{array}$ & Bab VIII Ketentuan Pidana Pasal 55-58 \\
\hline 10. & $\begin{array}{l}\text { Undang-Undang Nomor } 20 \text { Tahun } \\
2016 \text { tentang Merek dan Indikasi } \\
\text { Geografis }\end{array}$ & $\begin{array}{l}\text { Bab XVII Penyidikan Pasal } 100 \\
\text { Bab XVIII Ketentuan Pidana Pasal 100-103 }\end{array}$ \\
\hline 11. & $\begin{array}{l}\text { Undang-Undang Nomor } 19 \text { Tahun } \\
2016 \text { tentang Perubahan atas } \\
\text { Undang-Undang Nomor 11 Tahun } \\
2008 \text { tentang Informasi dan } \\
\text { Transaksi Elektronik } \\
\end{array}$ & $\begin{array}{l}\text { Penyidikan Pasal } 43 \\
\text { Ketentuan Pidana Pasal 45, 45A, dan 45B }\end{array}$ \\
\hline 12. & $\begin{array}{l}\text { Undang-Undang Nomor } 17 \text { Tahun } \\
2016 \text { tentang Penetapan Peraturan } \\
\text { Pemerintah Pengganti Undang- } \\
\text { Undang Nomor } 1 \text { Tahun } 2016 \\
\text { tentang Perubahan Kedua atas } \\
\text { Undang-Undang Nomor } 23 \text { Tahun } \\
2002 \text { tentang Perlindungan Anak } \\
\text { menjadi Undang-Undang }\end{array}$ & Pasal 81, 81A, 82, 82A, \\
\hline 13. & $\begin{array}{l}\text { Undang-Undang Nomor } 13 \text { Tahun } \\
2016 \text { tentang Paten }\end{array}$ & $\begin{array}{l}\text { Bab XV Penyidikan Pasal } 159 \\
\text { Bab XVII Ketentuan Pidana Pasal 161-166 }\end{array}$ \\
\hline 14. & $\begin{array}{l}\text { Undang-Undang Nomor } 11 \text { Tahun } \\
2016 \text { tentang Pengampunan Pajak }\end{array}$ & Bab XI Ketentuan Pidana Pasal 23 \\
\hline 15. & $\begin{array}{l}\text { Undang-Undang Nomor } 10 \text { Tahun } \\
2016 \text { tentang Perubahan Kedua atas } \\
\text { Undang-Undang Nomor } 1 \text { Tahun } \\
2015 \text { tentang Penetapan Peraturan } \\
\text { Pemerintah Pengganti Undang- } \\
\text { Undang Nomor 1 Tahun 2014 } \\
\text { tentang Pemilihan Gubernur, } \\
\text { Bupati, dan Walikota menjadi } \\
\text { Undang-Undang }\end{array}$ & $\begin{array}{l}\text { Pasal } 177 \mathrm{~A}, 177 \mathrm{~B}, 178 \mathrm{~A}, 178 \mathrm{~B}, 178 \mathrm{C}, 178 \mathrm{D}, \\
178 \mathrm{E}, 178 \mathrm{~F}, 178 \mathrm{G}, 178 \mathrm{H}, 180,182 \mathrm{~A}, 182 \mathrm{~B}, \\
185 \mathrm{~A}, 185 \mathrm{~B}, 186 \mathrm{~A}, 187 \mathrm{~A}, 187 \mathrm{~B}, 187 \mathrm{C}, 187 \mathrm{D}, \\
190 \mathrm{~A}, 193,193 \mathrm{~A}, 193 \mathrm{~B}, 198 \mathrm{~A},\end{array}$ \\
\hline 16. & $\begin{array}{l}\text { Undang-Undang Nomor } 9 \text { Tahun } \\
2016 \text { tentang Penvegahan } \\
\text { Sistem Keuangan }\end{array}$ & Bab V Ketentuan Pidana Pasal 47 \\
\hline 17. & $\begin{array}{l}\text { Undang-Undang } \text { Nomor } 8 \text { Tahun } \\
2016 \text { tentang } \quad \text { Penyandang } \\
\text { Disabilitas }\end{array}$ & Bab XI Ketentuan Pidana Pasal 144-145 \\
\hline
\end{tabular}




\begin{tabular}{llll}
\hline 18. Undang-Undang Nomor 7 Tahun & Bab IX Ketentuan Pidana Pasal 73-74 \\
2016 tentang Perlindungan dan & \\
Pemberdayaan Nelayan, Pembudi & \\
Daya Ikan dan Petambak Garam & \\
\hline 19. & Undang-Undang Nomor 1 Tahun & Bab XIV Ketentuan Pidana Pasal 57-59 \\
& 2016 tentang Penjaminan & \\
\hline 20. & Undang-Undang Nomor 1 Tahun & Ketentuan Pidana Pasal 177-198 \\
& 2015 tentang Penetapan Peraturan & \\
Pemerintah Pengganti Undang- \\
Undang Nomor 1 Tahun 2014 \\
tentang Pemilihan Gubernur, \\
Bupati, dan Walikota menjadi \\
Undang-Undang
\end{tabular}

Dengan beranjak pada undang-undang sebagaimana disebutkan diatas, salah satu masalah yuridis yang terdapat dalam kebijakan formulasinya adalah tidak adanya penetapan kualifikasi tindak pidana berupa kejahatan atau pelanggaran. Dari seluruh undang-undang yang memuat ketentuan pidana yang diundangkan pada tahun 2015-2019 hanya 1 (satu) undang-undang yang menetapkan deliknya sebagai kejahatan atau pelanggaran, selebihnya tidak menetapkan kualifikasi yuridis tersebut. Ketentuan Pidana dalam suatu undang-undang yang tidak menyebutkan kualifikasi yuridis terhadap delik yang diaturnya berupa kejahatan atau pelanggaran, tentu ini akan menimbulkan masalah yuridis. Setiap tindak pidana yang ditetapkan oleh pembentuk undangundang seharusnya disertai dengan kualifikasi terhadap deliknya, apakah masuk kategori kejahatan atau pelanggaran. Kualifikasi yuridis berupa kejahatan dan pelanggaran yang ditetapkan dalam KUHP mengandung konsekuensi yuridis. Konsekuensinya adalah adanya perbedaan aturan umum pemidanaan bagi kejahatan dan pelanggaran. Sehingga untuk dapat menjembatani berlakunya aturan umum pemidanaan dalam Bab I-VIII Buku I KUHP harus ditetapkan kualifikasi yuridis setiap tindak pidana yang dirumuskan dalam UU diluar KUHP.

Aturan umum pemidanaan mengenai "percobaan dan pembantuan", "concursus", "daluwarsa penuntutan dan pelaksanaan pidana, "dalam hal delik aduan" dan sebagainya yang terdapat dalam Buku I KUHP menjadi sulit untuk digunakan. Hal ini karena ada persyaratan dirumuskan dahulu kualifikasi yuridis terhadap deliknya baru dapat menerapkannya. Dalam rangka membuktikan adanya perbedaan aturan umum pemidanaan bagi kejahatan dan pelanggaran berikut disajikan dalam tabel di bawah ini:

Tabel 2.

Perbedaan Aturan Umum Pemidanaan dalam Buku I KUHP

\begin{tabular}{|c|c|c|}
\hline $\begin{array}{c}\text { Jenis Aturan Umum } \\
\text { Pemidanaan }\end{array}$ & Kejahatan & Pelanggaran \\
\hline Percobaan & $\begin{array}{l}\text { Mencoba melakukan } \\
\text { kejahatan dipidana..... (Pasal } \\
\text { 53) }\end{array}$ & $\begin{array}{lrr}\begin{array}{l}\text { Mencoba } \\
\text { pelanggaran } \\
\text { (Pasal 54) }\end{array} & \text { tidak } & \text { dipidana } \\
\end{array}$ \\
\hline Pembantuan & $\begin{array}{l}\text { Dipidana sebagai pembantu } \\
\text { suatu kejahatan ...... (Pasal } \\
56 \text { ) }\end{array}$ & \begin{tabular}{lrr} 
Membantu & \multicolumn{2}{c}{ melakukan } \\
pelanggaran & tidak & dipidana \\
(Pasal 60) & & \\
\end{tabular} \\
\hline Daluwarsa & $\begin{array}{lr}\text { Kewenangan } & \text { menuntut } \\
\text { pidana hapus } & \text { karena } \\
\text { daluwarsa: } & \\
\text { Ke-2: mengenai } & \text { kejahatan } \\
\text { yang diancam dengan denda, } \\
\text { kurungan, atau pidana }\end{array}$ & $\begin{array}{l}\text { Kewenangan menuntut pidana } \\
\text { hapus karena daluwarsa: } \\
\text { Ke-1: mengenai semua } \\
\text { pelanggaran dan kejahatan yang } \\
\text { dilakukan dengan percetakan, } \\
\text { sesudah satu tahun; }\end{array}$ \\
\hline
\end{tabular}




\begin{tabular}{l}
\hline penjara paling lama tiga \\
tahun, sesudah enam tahun; \\
Ke-3: mengenai kejahatan \\
yang diancam dengan pidana \\
penjara lebih dari tiga tahun, \\
sesudah dua belas tahun; \\
Ke-4. Mengenai kejahatan \\
yang diancam dengan pidana \\
mati atau pidana penjara \\
seumur hidup, sesudah \\
delapan belas tahun. \\
\hline
\end{tabular}

Uraian di atas menunjukkan bahwa penetapan kualifikasi yuridis berupa kejahatan dan pelanggaran mengandung konsekuensi hukum untuk dapat menjembatani berlakunya ketentuan umum dalam Buku I KUHP.

\section{KESIMPULAN}

Bab Ketentuan Pidana dalam berbagai undang-undang tersebut merupakan bentuk kebijakan formulasi. Kajian yang telah dilakukan menyimpulkan formulasi ketentuan pidana dalam berbagai undang-undang tersebut mengandung masalah yuridis, antara lain terdapat 19 undang-undang yang tidak menetapkan kualifikasi yuridis berupa kejahatan atau pelanggaran.

Ucapan Terima Kasih (Acknowledgement)

Ucapan terima kasih kepada Lembaga Penelitian dan Pengabdian kepada Masyarakat (LPPM) Universitas Tarumanagara dan berbagai pihak yang telah membantu.

\section{REFERENSI}

Arief, B. N. (2016). Kebijakan formulasi ketentuan pidana dalam peraturan perundangundangan. Pustaka Magister.

Arief, B. N. (2012). Pembangunan sistem hukum nasional (Indonesia). Pustaka Magister.

Chynoweth, P. (2008). Legal Research in the built environment: A methodological framework. University of Salford.

UN. Secretariat, \& UN. Department of International Economic and Social Affairs. (1985). Seventh United Nations Congress on the prevention of crime and the treatment of offenders, Milan, 26 August-6 September 1985 : report / prepared by the Secretariat. UN Congress on the Prevention of Crime and the Treatment of Offenders (7th : 1985 : Milan, Italy) (DHLAUTH)14591. (pp. 3).

Undang-Undang Nomor 1 Tahun 2014 tentang Pemilihan Gubernur, Bupati, dan Walikota menjadi Undang-Undang. (Indonesia).

Undang-Undang Nomor 1 Tahun 2015 tentang Penetapan Peraturan Pemerintah Pengganti. (Indonesia).

Undang-Undang Nomor 1 Tahun 2016 tentang Penjaminan. (Indonesia).

Undang-Undang Nomor 1 Tahun 2018 tentang Kepalangmerahan. (Indonesia).

Undang-Undang Nomor 6 Tahun 2018 tentang Kekarantinaan Kesehatan. (Indonesia).

Undang-Undang Nomor 5 Tahun 2017 tentang Pemajuan Kebudayaan. (Indonesia).

Undang-Undang Nomor 7 Tahun 2016 tentang Perlindungan dan Pemberdayaan Nelayan,

Pembudi Daya Ikan dan Petambak Garam. (Indonesia).

Undang-Undang Nomor 7 Tahun 2017 tentang Pemilihan Umum. (Indonesia).

Undang-Undang Nomor 8 Tahun 2016 tentang Penyandang Disabilitas. (Indonesia). 
Undang-Undang Nomor 8 Tahun 2019 tentang Penyelenggaraan Ibadah Hajii dan Umroh. (Indonesia).

Undang-Undang Nomor 9 Tahun 2016 tentang Penyegahan Krisis Sistem Keuangan. (Indonesia). Undang-Undang Nomor 9 Tahun 2018 tentang Penerimaan Negara Bukan Pajak. (Indonesia).

Undang-Undang Nomor 10 Tahun 2016 tentang Perubahan Kedua atas Undang-Undang Nomor 1 Tahun 2015 tentang Penetapan Peraturan Pemerintah Pengganti Undang-Undang Nomor 1 Tahun 2014 tentang Pemilihan Gubernur, Bupati, dan Walikota menjadi Undang-Undang. (Indonesia).

Undang-Undang Nomor 11 Tahun 2016 tentang Pengampunan Pajak. (Indonesia).

Undang-Undang Nomor 13 Tahun 2016 tentang Paten. (Indonesia).

Undang-Undang Nomor 16 Tahun 2017 tentang Penetapan Peraturan Pemerintah Pengganti Undang-Undang Nomor 2 Tahun 2017 tentang Perubahan atas Undang-Undang Nomor 2 Tahun 2013 tentang Organisasi Kemasyarakatan Menjadi Undang-Undang. (Indonesia).

Undang-Undang Nomor 17 Tahun 2016 tentang Penetapan Peraturan Pemerintah Pengganti Undang-Undang Nomor 1 Tahun 2016 tentang Perubahan Kedua atas Undang-Undang Nomor 23 Tahun 2002 tentang Perlindungan Anak menjadi Undang-Undang. (Indonesia). Undang-Undang Nomor 18 Tahun 2017 tentang Perlindungan Pekerja Migran Indonesia. (Indonesia).

Undang-Undang Nomor 19 Tahun 2016 tentang Perubahan atas Undang-Undang Nomor 11 Tahun 2008 tentang Informasi dan Transaksi Elektronik. (Indonesia).

Undang-Undang Nomor 20 Tahun 2016 tentang Merek dan Indikasi Geografis. (Indonesia). 